\title{
Fonksiyonel Bir Besin: Kefir
}

\section{A Functional Food: Kefir}

\section{Ezgi Bellikci Koyu' ${ }^{1}$, Zehra Büyüktuncer Demirel ${ }^{2}$}

Geliş tarihi/Received: 27.06.2018 • Kabul tarihi/Accepted: 18.08.2018

\section{ÖZET}

Fermente süt ürünleri arasında önemli bir yeri olan ve ülkemizde de geleneksel olarak tüketilen kefir, probiyotik özellikte birçok mikroorganizma içeren fonksiyonel bir içecektir. Kefir geleneksel olarak, bakterilerin ve mayaların simbiyotik olarak birlikte yaşadığı spesifik ve kompleks bir bileşime sahip olan kefir danelerinden üretilir. Kefirin mikrobiyal bileşimi ve besin ögesi örüntüsü kullanılan kültürün türü ve miktarı, kullanılan sütün cinsi, sütün bileşimi, kültür ortamı, fermantasyon süresi, fermantasyon sıcaklığı ve depolama koşullarına göre değişiklik göstermektedir. Bununla birlikte, Lactobacillus, Lactococcus, Leuconostoc cinsi bakteriler ve asetik asit bakterileri kefirde en fazla bulunan bakteriler, Saccharomyces, Kluyveromyces ve Candida cinsi mantarlar ise kefirde fazla bulunan mayalardır. Son yıllarda yapılan çalışmalar kefirin ve/veya kefirden izole edilen bakterilerin sağlık üzerine çeşitli yararları olduğuna işaret etmektedir. Çalışmalarda, kefirin antikarsinojenik, antimikrobiyal, anti-inflamatuvar ve antihipertansif etki gösterdiği, ayrıca sindirim sisteminin düzenlenmesinde, vücut ağırlığının denetiminde, lipit profilinin ve glisemik yanıtın kontrolünde yardımcı olabileceği gösterilmiştir. Bu derlemede, kefir ve kefir danesinin özellikleri, kefir üretimi, kefirin besin ögesi ve mikrobiyal bileşimi ile sağlık üzerine olan yararları ele alınmıştır.

Anahtar kelimeler: Kefir, probiyotik, fermente süt ürünleri, fonksiyonel özellikler, sağllk

\begin{abstract}
Kefir, which has an important place among the fermented milk products and is consumed traditionally in our country, is a functional drink with many probiotic microorganisms. Kefir is traditionally produced from kefir grains, which have a specific and complex composition that bacteria and yeasts live together symbiotically. The microbial and nutritional composition of kefir varies according to the type and amount of grains used, type and composition of milk used, culture medium, fermentation period, fermentation temperature and storage conditions. Lactobacillus, Lactococcus, Leuconostoc and acetic acid bacteria are the most common bacteria; Saccharomyces, Kluyveromyces and Candida species are mostly found yeast in kefir. Studies conducted in recent years indicate that kefir and/or bacteria isolated from kefir have various health benefits. Studies have shown that kefir has anticarcinogenic, antimicrobial, anti-inflammatory and antihypertensive activities and may also help regulation of the digestive system, management of body weight, control of hyperlipidemia and glycemic response. In this review, properties of kefir and kefir grains, kefir production, kefir's nutritional and microbial composition and health benefits were discussed.
\end{abstract}

Keywords: Kefir, probiotic, fermented milk products, functional properties, health

1. İzmir Kâtip Çelebi Üniversitesi, Sağllk Bilimleri Fakültesi, Beslenme ve Diyetetik Bölümü, İzmir, Türkiye

○ https://orcid.org/0000-0001-5279-2394
2. İletişim/Correspondence: Hacettepe Üniversitesi, Sağllk Bilimleri Fakültesi, Beslenme ve Diyetetik Bölümü, Ankara, Türkiye

E-posta: zbtuncer@hacettepe.edu.tr • ๑ https://orcid.org/0000-0002-2039-8568 


\section{GíRiş}

Bulgar köylülerinin sağlıklı ve uzun yaşam sırrı olarak gösterilen fermente süt ürünleri, yeterli ve dengeli diyetin önemli bileşenlerindendir. Kafkas dağlarından köken alan ve ülkemizde de geleneksel olarak tüketilen bir içecek olan kefir, asidik, fermente bir süt ürünüdür (1,2). Kefir kelimesinin, iyi hissetme, iyi yaşama anlamına gelen Keif-Keyif kökünden türediği düşünülmektedir (1-4). Rusya, Doğu ve Kuzey Avrupa, Güneybatı Asya gibi bölgelerde yaygın olarak tüketilen kefir, kephir, kefyr, kiaphur, kefer, kipi, knapon ve kippi gibi farklı isimlerle de bilinmektedir $(1,4)$. Bu derleme çalışmada, kefirin beslenme ve sağlık üzerine olan etkilerinin değerlendirilmesi amaçlanmıştır.

\section{Kefir Danesi}

Geleneksel olarak kefir, kefir danelerinden üretilir. Bu yönüyle, diğer fermente süt ürünlerinden farklıdır (2). Kefir daneleri şekilsel olarak karnabahara benzeyen, elastik, düzensiz, jelimsi özellikte, beyaz-sarımtırak renkte ve 3-35 mm çapında yapılardır $(2,3)$. Koçak ve Gürsel'in 1981 yılındaki yayınlarında kefir danesinin elde edilişi şu şekilde anlatılmıştır:

“Kefir daneleri, Kafkasya’da keçi tulumu içinde, inek sütünün dana ve koyun şirdenleri ile pıhtılaştırılması sonucunda elde edilir. Pıhtılaştırmanın yapıldığı tulumun iç yüzeyinde birkaç hafta sonra süngerimsi bir kabuk tabakası oluşur. Bu kabuk tabakası alınır ve bölünerek kurutulur. Kurutma sonucunda oluşan küçük topaklar kefir daneleridir” (5).

Kefir daneleri, kazein ve polisakkaritlerden oluşmuş bir matriks içinde, laktik asit ve asetik asit üreten bakterilerle çeşitli mayaların simbiyotik birlikteliğinden oluşmaktadır (3). Kefiran, kefirin dış yüzeyindeki temel polisakkarit olup, yapısında 1:1 oranında D-glukoz ve D-galaktoz bulunmaktadır. Kefiran oluşumu, genellikle danelerdeki Lactobacillus kefiranofaciens ve Lactobacillus kefiri ile ilişkilidir $(2,3)$.

\section{Kefir Üretimi}

Kefir üretimi için en yaygın olarak inek sütü kullanılmakla birlikte, keçi, koyun, deve gibi farklı hayvanların sütlerinden ya da soya, pirinç, hindistan cevizi sütü gibi bitkisel kaynaklardan da kefir üretilebilir. Kefir, tam yağlı, yarım yağlı ya da yağsız pastörize sütten hazırlanabilir $(2,3)$.

Kefir üretiminin 2 temel yöntemi vardır. Birincisi çoğunlukla evlerde kullanılan geleneksel yöntem, ikicisi ise endüstriyel yöntemdir (Şekil 1). İlk yöntemde, başlangıç kültürü olarak kefir daneleri kullanır ve pastörize inek sütüne eklenir. Dane süt oranı olarak 1:30-1:50 ağırlık/hacim gibi ideal bir oran belirlenmiş olmakla birlikte, geleneksel olarak evlerde üretilirken miktarlar ampirik olarak belirlenir. Kefir danelerinin süte eklenmesinin ardından, kapalı bir kapta, $8-25^{\circ} \mathrm{C}$ arasında değişen sıcaklıklarda, 10-40 saat boyunca fermantasyon işlemi gerçekleştirilir (2). Bununla birlikte, yaygın olarak $20-25^{\circ} \mathrm{C}$ 'lik sıcaklık ve 18-24 saatlik fermantasyon süresi tercih edilmektedir (3). Fermantasyondan sonra, daneler bir süzgeç yardımıyla fermente olan sütten ayrılır. Kefir, daneler ayrıldıktan hemen sonra tüketilebilir ya da daha sonra tüketilmesi için buzdolabında saklanabilir. Soğutma sırasında, olgunlaşma ile aroma bileşenleri de $\operatorname{artar}(2,4)$.

Fermantasyon sonunda kefir daneleri boyutlarını yaklaşık \%2-7 oranında arttırır. Böylece sürekli olarak üretim sağlanabilir ve kefir daneleri tekrar kullanılabilir. Daneler çeşitli şekillerde saklanabilir. Kefir daneleri, $4^{\circ} \mathrm{C}^{\prime}$ de saklandiğı zaman 8-10 gün süreyle aktif kalırlar. Oda sıcaklığında 36-48 saat kurutma ile 12-18 ay arasinda saklanabilir $(2,4)$. Garotte ve arkadaşları (6), $-20^{\circ} \mathrm{C}^{\prime}$ de dondurma işleminin daneleri saklamak için en iyi yol olduğunu bildirmişlerdir. Kefir daneleri uygun koşullarda depolanırsa, aktivitesini kaybetmeden uzun ylllar saklanabilir. Saklanan kefir daneleri, sütün içine başarılıbir şekilde inkübe edilirse, daneler ağırlıklarını arttırarak eski yapılarına tekrar kavuşabilir (2). 
Kefirin endüstriyel üretiminde ise başlangıç kültürü olarak, kefir danesi yerine kefir danelerinden hazırlanmış ana kültür/bulk kültür (Rus yöntemi) veya kefir ya da kefir danelerinden izole edilen mikroorganizmaları içeren saf ticari kültürler (\%28) kullanılır (Şekil 1) (4,7). Üretimde ticari kültür kullanılması, standart bir ürün elde edilebilmesini sağlar (4)

\section{Çiğ süt}

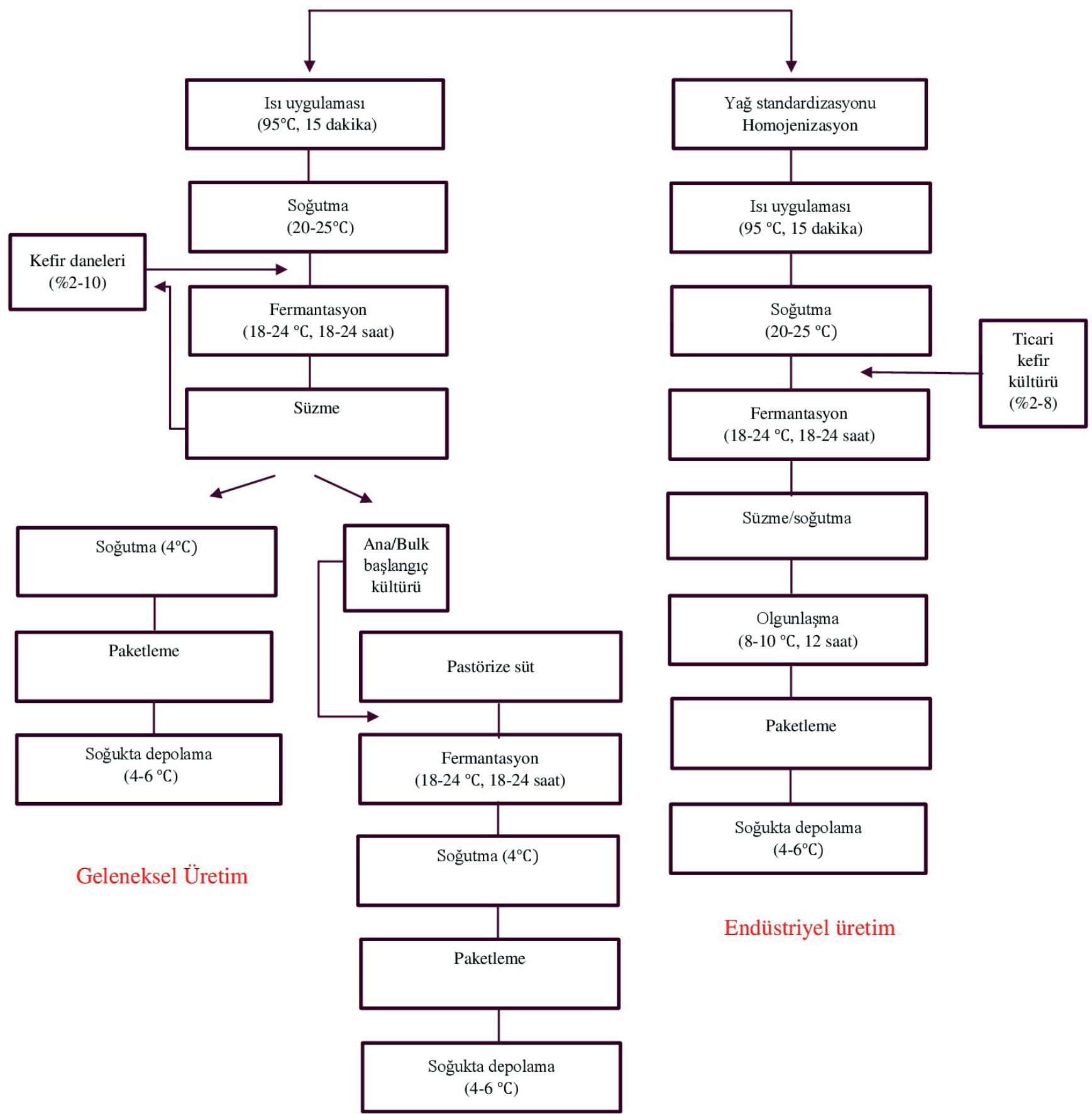

Rus/Avrupa Metodu

Şekil 1. Kefir üretimi $(4,7)$ 


\section{Kefirin Besin Ögesi Bileşimi}

Kefirin besin ögesi bileşimi, sütün bileşimi, kullanılan başlangıç kültürü, fermantasyon sıcaklığı, fermantasyon süresi ve depolama koşullarına göre değişiklik gösterir (1,2). Türk Gida Kompozisyonu Veri Tabanı'na göre 100 g kefirin bileşimde \%88$89 \mathrm{su}$, \%3-6 karbonhidrat, \%3-3.3 protein ve \%1.63.6 yağ bulunmaktadır. Kefir, kalsiyum, fosfor, magnezyum ve potasyum gibi mineraller ve B grubu vitaminler açısından iyi bir kaynaktır (Tablo 1) (8). Bunun yanı sıra kefir, düşük miktarda alkol (\%0.52) ve laktik asit (\%0.8-1.0) içermektedir. Laktik asit, fermantasyon aşamasında oluşmaktadır. Kefirin fermantasyonu sırasında, sütteki laktozun \%30’u bakteriyel $\beta$-galaktosidaz enzimi ile hidrolize edilerek glukoz ve galaktoza dönüştürülür. Oluşan glukoz da, kefir bakterileri tarafindan laktik aside dönüştürülür (2). Kefirdeki alkol ve $\mathrm{CO}_{2}$ ise, temel olarak mayaların faaliyeti sonucunda oluşmaktadır (7). Kefirdeki $\mathrm{CO}_{2}$ miktarı, kullanılan kefir danesinin miktarına paralel olarak artar (1). Kefirin pH’ı 4.2-4.6 arasındadır (2).

Tablo 1. Kefirin enerji ve besin ögesi içeriği (8)

\begin{tabular}{lc}
\hline Besin ögesi & Ortalama miktar* \\
\hline Enerji (kkal) & 55 \\
Su (g) & 89.0 \\
Karbonhidrat (g) & 4.7 \\
Protein (g) & 3.1 \\
Yağ (g) & 2.6 \\
Kalsiyum (mg) & 107.0 \\
Fosfor (mg) & 78.0 \\
Potasyum (mg) & 172.0 \\
Çinko (mg) & 0.35 \\
A vitamini (RE) & 24.0 \\
E vitamini (IU) & 0.25 \\
Riboflavin (mg) & 0.16 \\
B $_{6}$ vitamini (mg) & 0.01 \\
$\mathrm{~B}_{12}$ vitamini $(\mu \mathrm{g})$ & 0.16 \\
\hline
\end{tabular}

*Ankara ve Kars kefirinin ortalaması olarak verilmiştir.

Türk Gida Kodeksi Fermente Süt Ürünleri Tebliğine göre kefir, en az \%2.7 protein ve \%0.6 oranında laktik içermeli, yağ oranı \%10’u geçmemelidir. Alkol oranına yönelik ise bir kural getirilmemiştir (9).

\section{Kefirin Mikrobiyolojik Bileşimi}

Kefir mikrobiyotası bakteri ve mayaların simbiyotik topluluğundan oluşan karmaşık bir sistemdir. Kefirin mikrobiyal bileşimi, kefir danelerinin ya da kullanılan kültürün bileşimi ve miktarı, kültür ortamı, fermantasyon süresi, fermantasyon sıcaklığı, sütün cinsi, bileşimi ve depolama koşullarına göre değişiklik göstermektedir (2). Temel olarak kefir mikrobiyotası, laktik asit ve asetik asit bakterileri ile laktozu fermente eden ve etmeyen mayalardan oluşmaktadır. Lactobacillus, Lactococcus, Leuconostoc cinsi bakteriler ve asetik asit bakterileri kefirde en fazla bulunan bakterilerdir (10). Saccharomyces, Kluyveromyces ve Candida cinsleri ise maya popülasyonun önemli bir kısmını oluşturmaktadır (11).

Türk Gıda Kodeksi Fermente Süt Ürünleri Tebliği’ne göre ise kefir, fermantasyonda spesifik olarak Lactobacillus kefiri, Leuconostoc, Lactococcus ve Acetobacter cinslerinin değişik suşları ile laktozu fermente eden (Kluyveromyces marxianus) ve etmeyen (Saccharomyces unisporus, Saccharomyces cerevisiae ve Saccharomyces exiguus) mayaları içeren başlangıç kültürlerinin ya da kefir danelerinin kullanıldığı fermente süt ürünü olarak tanımlanmaktadır (9).

Kefirin bileşimi kadar içeriğindeki bakteri ve mayaların sayısı da, ürünün kalitesi ve bioyararlanımı açısından önemlidir. Türk Gıda Kodeksi Fermente Süt Ürünleri Tebliği'nde, kefirdeki toplam spesifik mikroorganizma sayısının en az $10^{7}$ koloni oluşturan birim (kob)/g, maya sayısının ise en az $10^{4} \mathrm{kob} / \mathrm{g}$ olması gerektiği belirtilmiştir (9). Yapılan çalışmalarda, kefirdeki bakteri ve maya miktarının değişken olduğu gözlenmiştir. Depolama sürecinin de bu miktarlar üzerinde önemli etkisinin olabileceği saptanmıştır (12). Ülkemizde, özellikle ticari olarak üretilen kefirlerin yasal limitleri karşılamadığı ve probiyotik etki gösterebilecek düzeyde canlı mikroorganizma içermediğini bildiren çalışma da mevcuttur (13). $\mathrm{Bu}$ nedenle, kefirin sağllk üzerine olan etkisi değerlendirilirken, kullanılan ürün ve bileşimine dikkat edilmelidir. 


\section{Kefirin Sağlık Üzerine Etkileri}

Kefir mikrobiyotasında probiyotik özellikte birçok mikroorganizmanın olduğu belirlenmiştir. Yapılan çalışmalarda, kefirden izole edilen çeşitli bakterilerin ve mayaların, düşük $\mathrm{pH}$ ve safra asitlerine karşı dayanıklı olduğu, intestinal mukozaya tutunabildiği, patojenlere karşı güçlü antagonistik etki gösterdiği ve sağlık üzerine olumlu etkilerinin olduğu saptanmıştır (14-16). Çeşitli çalışmalarda kefirin antimikrobiyal, anti-inflamatuvar, antiallerjen ve antikarsinojenik etki gösterdiği, vücut ağırlığı, glisemik yanıt, kan basincı ve kan lipitlerinin kontrolünde etkili olabileceği, ayrıca laktoz intoleransı ve konstipasyon gibi sindirim sistemi sorunlarına karşı kullanabileceği bildirilmiştir (17-24).

Antimikrobiyal etki: Laktik asit bakterilerinin besin kaynaklı patojenlerin gelişimini engelleyerek antimikrobiyal etki gösterdiği bilinmektedir (25). Kefirle yapılan çalışmalarda da kefirin Bacillus cereus, Cronobacter sakazakii, Escherichia coli, Listeria monocytogenes, Pseudomonas aeruginosa, Salmonella enteritidis, Staphylococcus aureus gibi çeşitli mikroorganizmalara karşı antimikrobiyal etki gösterdiği saptanmıştır (21,26). Kahverengi şekerde kültüre edilmiş kefirin de Candida albicans, Salmonella typhi, Shigella sonnei, Staphylococcus aureus ve Escherichia coli'ye karşı etkili olduğu bildirilmiştir (27). Ayrıca, kefir danesinin temel polisakkariti olan kefiranın da antimikrobiyal aktivite gösterdiği saptanmıştır (28). Kefirin antimikrobiyal etkisi kefirin pH'l, fermantasyon sonucu oluşan biyoaktif peptitler, organik asitler ve hidrojen peroksit ile ilişkilendirilmektedir (1). Kullanılan kefir kültürü ve fermantasyon süresi de antimikrobiyal etkinliği etkilemektedir. Kim ve arkadaşlarının (21) yürüttükleri çalışmada, fermantasyon süresi 36-48 saat olan kefirlerin antimikrobiyal aktivitesinin daha yüksek olduğu belirlenmiştir.

Kefirin antimikrobiyal etkinliği desteklediği Helicobacter pylori'ye karşı da gösterilmiştir. Helicobacter pylori enfeksiyonu olan ve dispepsi şikayeti olan 82 hastanın dahil edildiği randomize çift kör bir çalışmada, standart tedaviye ek olarak 14 gün boyunca günlük $500 \mathrm{~mL}$ kefir ya da plasebo süt verilmiştir. Çalışma sonunda eradikasyon oranının kefir tüketenlerde (\%78.2) plasebo grubuna göre (\%50.0) daha yüksek olduğu ve standart tedaviye ek olarak kefir kullanımının Helicobacter pylori eradikasyonunda daha etkili olduğu sonucuna ulaşılmıştır (29).

Anti-inflamatuvar etki: İnflamasyon vücudun doku hasarına veya enfeksiyona karşı verdiği ve vücut homeostazının sağlanmasına yardımcı bir savunma mekanizmasıdır. Ancak, sistemik düşük düzeydeki kronik inflamasyonun, birçok kronik hastalığın patogenizinde rol aldığı düşünülmektedir (30). Probiyotiklerin intestinal epitel bariyerin yapısını ve fonksiyonunu destekleyerek ayrica inflamasyonla ilişkili çeşitli yolaklar üzerinden immün ve inflamatuvar yanıtı düzenleyebileceği bildirilmiştir (31). Bu kapsamda, hayvan modelleri üzerinde kefirin inflamatuvar yanıta etkisinin incelendiği çeşitli çalışmalar mevcuttur. Sıçanlarla yapılan bir çalışmada, hiperglisemi oluşturulmuş sıçanlarda sade kefirin 30 gün süreyle verilmesi, proinflamatuvar sitokinlerden interlökin-1 ve interlökin-6 (IL-6) düzeylerinde anlamlı azalma, anti-inflamatuvar sitokin olan interlökin-10 düzeylerinde ise anlamlı bir artış sağlamıştır (22). Yüksek yağlı diyet ile beslenmiş farelerde yapılan bir çalışmada, 12 hafta süreyle kefir verilmesinin benzer şekilde IL-6 düzeylerinde azalma sağladığı gösterilmiştir (32). Deneysel olarak astım modeli oluşturulan farelerde yürütülmüş bir çalışmada da, kefirin anti-inflamatuvar ve antialerjik etki gösterdiği belirlenmiştir (18). Kefirin inflamatuvar yanıt üzerine etkisini inceleyen klinik veriler ise henüz çok sinırlı olup (33), inflamatuvar hastalığı olan gruplarda planlanacak çalışmalara gereksinme olduğu söylenebilir.

Antikarsinojenik etki: Kefirin kanserden korunma ve kanser tedavisindeki etkinliğine yönelik olarak da çeşitli çalışmalar yürütülmüştür. Bu çalışmaların değerlendirildiği sistematik bir derlemede, kefirin meme kanseri, gastrik kanser, kolon adenokarsinoma, melanoma velösemi hücre hatlarında antikarsinojenik 
etki gösterdiği bildirilmiştir (20). Yapılan, in vivo çalışmalarda da kefirin tümör hücrelerinin büyümesini engellediği ve tümör çapını küçülttüğü rapor edilmiştir $(34,35)$. Kefirin bu etkisinde biyoaktif peptitler, polisakkaritler ve sifingolipitlerin de rol alabileceği bildirilmiştir (20).

Kefirin vücut ağırlığı üzerine etkisi: Yapılan epidemiyolojik çalışmaların sonuçları yoğurt gibi fermente süt ürünlerinden zengin bir diyetin obezite riskini azalttığını göstermektedir (36). Bu ilişkide kalsiyumun yanı sıra fermente süt ürünlerindeki biyoaktif peptitlerin ve probiyotiklerin de rolü olabileceği düşünülmektedir. Kefirin vücut ağırlığı üzerine etkisinin incelendiği hayvan modelleri ile yapılan çalışmalarda, kefir tüketiminin yüksek yağlı diyete bağlı gelişen obeziteye karşı koruyuculuk gösterdiği saptanmıştır (23,32). Choi ve arkadaşlarının (23) sıçanlarla yürüttükleri bir çalışmada, yüksek yağlı diyete $\% 0.1$ veya $\% 0.2$ oranında kefir tozu (Leuconostoc mesenteroides, Lactobacillus kefiri ve Kluyveromyces marxianus) eklenmesinin yüksek yağlı diyetin neden olduğu aşırı yağ birikimini ve vücut ağırlığı artışını azalttığı gösterilmiştir. Çalışmada, kefirin bu etkisini adipogenez ve lipogenez ile ilişkili genlerin ekspresyonlarını azaltarak gösterdiği saptanmıştır. Farelerle yapılan başka bir çalışmada, yüksek yağlı diyete ek olarak laktik asit, asetik asit bakterileri ile Candida ve Saccharomyces cinsi mayaları içeren kefir ya da süt 12 hafta süreyle verilmiştir. Kefir alan gruptaki farelerin süt alan gruptakilere göre vücut ağırlığı artışının daha az olduğu saptanmıştır (32).

Kefirin klinik çalışmalardaki etkisine bakıldığında ise çalışmaların henüz sınırlı olduğu söylenebilir. Fathi ve arkadaşlarının (37) çalışmasında, hafif şişman ve obez kadınlarda ( $n=58)$ kefir ve sütün ağırlık kaybı üzerine olan etkisi karşılaştırılmıştır. Çalışmada kadınlar kefir, süt ve kontrol grubu olmak üzere üç gruba ayrılmıştır. Kontrol grubuna günlük 2 porsiyon az yağlı süt ürünleri içeren ağırlık koruyucu bir diyet verilmiştir. Kefir ve süt alan gruptaki kadınlara ise kontrol grubundaki önerilere ek olarak ekstra 2 porsiyon süt ya da kefir (toplam 4 porsiyon süt ürünü/ gün) verilmiştir. Çalışmanın 8 haftalık müdahalesi sonunda gruplardaki vücut ağırlığındaki ortalama azalma sirasıyla kefir alan grup için $2.4 \mathrm{~kg}$, süt alan grup için $2.1 \mathrm{~kg}$, kontrol grubu için $1.0 \mathrm{~kg}$ olarak bulunmuştur. Bel çevresi değerlerinde ise kefir alan grupta $2.1 \mathrm{~cm}$, süt alan grupta $2.0 \mathrm{~cm}$, kontrol grubunda ise $0.9 \mathrm{~cm}$ azalma olduğu belirlenmiştir. Antropometrik ölçümler açısından gruplar karşılaştırıldığında kefir ve süt alan gruplar arasında değişimlerin benzer olduğu, bu gruplardaki değişimin kontrol grubuna göre ise farklılık gösterdiği belirlenmiştir. Bu bulgular, süt ve kefir alan gruplarda gözlenen ağırlık kaybının çalışmadaki yüksek miktarda süt ürünü tüketimi ve dolayısıyla yüksek kalsiyum alımı ile ilişkili olabileceğini düşündürmektedir. Kefirin kalsiyumdan bağımsız olarak vücut ağırlığı üzerine etkisinin olup olmadığını değerlendirmek için ise yeni çalışmalara gerek olduğu söylenebilir.

Kefirin lipit profiline etkisi: Probiyotiklerin hiperlipidemi üzerine etkisi birçok çalışmada incelenmiş ve yaplan meta analizlerde probiyotik müdahalelerinin total kolesterol düzeyinde ortalama 6.6-10.4 mg/dL, düşük yoğunluklu lipoprotein (LDL) kolesterol düzeyinde ise ortalama $7.3-8.9 \mathrm{mg} / \mathrm{dL}$ azalma sağladığı saptanmıştır (38-40). Kefir ve kefiran ile yürütülmüş çalışmalar incelendiğinde ise hayvan modelleri ile yapılan çalışmaların sonuçları umut vaat etmekle birlikte $(24,41)$, klinik çalışmaların sonuçları kefirin serum lipit profili üzerine etkisinin sinırlı ve süt ile benzer olduğunu göstermektedir. Premenapozal dönemdeki kadınlarla yürütülen bir çalışmada günlük 2 porsiyon az yağlı süt ürünlerine ek olarak 2 porsiyon kefir tüketiminin total kolesterol ve LDL kolesterolde başlangıca göre sırasıyla $10.4 \mathrm{mg} /$ dL ve $9.7 \mathrm{mg} / \mathrm{dL}$ oranında anlamlı azalma sağladığı belirlenmiştir. Ancak aynı çalışmada, kefir yerine süt verilmesinin de benzer etki gösterdiği rapor edilmiştir (37). Hiperlipidemisi olan 13 erkek bireyle yürütülen randomize çaprazlama bir çalışmada, 4 hafta süreyle günlük 500 mL kefir ya da az yağlı süt tüketiminin serum total kolesterol, LDL kolesterol, yüksek yoğunluklu lipoprotein (HDL) kolesterol ve trigliserit düzeylerini etkilemediği bulunmuştur (42). Ostadrahimi ve arkadaşları (43) tarafından yürütülen 
bir çalışmada ise, 8 hafta süreyle günlük $600 \mathrm{~mL}$ kefir ve ayran tüketimi karşılaştırılmıştır. Çalışma sonunda her iki grubun da total kolesterol, trigliserit, LDL kolesterol değerlerinin azalma eğiliminde olduğu ancak değişimlerin istatistiksel açıdan anlamlı olmadığı belirlenmiştir.

Kefir ve hiperlipidemi ilişkisine yönelik bu çelişkili sonuçlar incelenen grubun özellikleri ve çalışmalarda kullanılan kefir kültürlerinin farklılığı ile ilişkili olabilir. Örneğin Ostadrahimi ve arkadaşlarının (43) çalışmasında incelenen grubun başlangıç total kolesterol ve LDL kolesterol düzeylerinin yüksek olmaması istatistiksel açıdan anlamlı bir etki görülmemesinin nedeni olabilir. Bu doğrultuda, kefir ve hiperlipidemi arasındaki ilişkinin net olarak ortaya konulabilmesi için, in-vivo çalışmalarda yüksek potansiyel gösteren suşları içeren kefirle dislipidemik bireylerde yürütülecek iyi planlanmış klinik çalışmalara gerek olduğu söylenebilir.

Kefirin kan basıncina etkisi: Probiyotiklerin hipertansiyon ile ilişkisi sık araştırılan bir konu olup, probiyotiklerin inflamatuvar yanıtı ve vasküler oksidatif stresi azaltarak, nitrik oksit (NO) düzeylerini ise arttırarak kan basıncının düzenlenmesine yardımcı olabileceği öne sürülmüştür (44). Ayrıca, fermente ürünlerde, fermantasyon sırasında oluşan biyoaktif peptidlerin de, anjitotensin II oluşumunu baskılayarak kan basıncını düşürmede etkili olabileceği bildirilmiştir (45). Buna karşılık literatürde kefirin hipertansiyon ile ilişkisinin incelendiği çalışmalar henüz sınırlı olup, yapılan araştırmalar genellikle hayvan modelleri üzerinde yürütülmüştür. Spontan hipertansiyon geliştirilmiş sıçanlarda Acetobacter aceti, Acetobacter sp., Lactobacillus delbrueckii, Lactobacillus fermentum, Lactobacillus fructivorans, Enterococcus faecium, Leuconostoc spp., Lactobacillus kefiranofaciens bakterilerini ve maya olarak Candida famata ile Candida krusei içeren kefirin 60 gün sonunda kan basıncında yaklaşı \%15 oranında azalma sağladığı ve reaktif oksijen türleri ile NO dengesini düzenleyerek endotel fonksiyonu iyileştirdiği saptanmıştır (46). Kanbak ve arkadaşlarının (47) yürüttükleri çalışmada da benzer bulgular rapor edilmiştir. Rosa ve arkadaşları (48) ise metabolik sendrom geliştirilmiş sıçanlarda kefirin antihipertansif etki oluşturmadığını bildirmiştir.

Kefirin glisemik yanıt üzerine etkisi: Kefirin glisemik yanıt üzerine olan etkisi de son yllarda araştırılmaya başlanmıştır. Hadisaputro ve arkadaşlarının (22) yürüttükleri in-vivo bir çalışmada, diyabet geliştirilmiş sıçanlarda 30 gün süre ile kefir tüketiminin açlık kan glukozunu kontrol grubuna göre anlamlı olarak azalttığı saptanmıştır. Konu ile ilişkili yürütülen klinik bir çalışmada da tip 2 diyabetik bireylerde 8 hafta süreyle günlük 600 g kefir tüketiminin kontrol içeceği olan ayrana göre açlık kan glukozunu (başlangıç= $161.6 \pm 57.71 \mathrm{mg} / \mathrm{dL}$, bitiş= 139.2 $\pm 46.66 \mathrm{mg} / \mathrm{dL}$ ) ve Hemoglobin A1c (HbA1c) düzeylerini (başlangıç= \%7.6 \pm 1.22 , bitiş= \%6.4 \pm 1.91 ) anlamlı olarak azalttığı gösterilmiştir. Probiyotiklerin ve kefirin oksidatif stresi azaltarak, bağırsak hormon düzeylerini düzenleyerek ve bağırsaklardan glukoz emilimini azaltarak glisemik kontrole yardımcı olabileceği bildirilmiştir (43).

\section{Kefirin bağırsak sağlığı üzerine etkileri:} Probiyotiklerin en iyi bilinen etkilerinden birisi sindirim sistemini düzenleyici etkileridir. $\mathrm{Bu}$ etki ile ilişkili olarak ülkemizde probiyotik besinlerin etiketinde sağlık beyanına da izin verilmiştir (49). Buna karşllık fermente süt ürünleri ve kefir ile yürütülmüş çalışmalar çok sinırlıdır. Kefir ve konstipasyon arasındaki ilişkinin incelendiği pilot bir çalışmada, fonksiyonel konstipasyonu olan bireylerde, 4 hafta süreyle günlük $500 \mathrm{~mL}$ kefir tüketiminin defekasyon parametrelerinde (dışkılama sıklığı, dışkının kıvamı, laksatif kullanım oranı) gelişme sağladı̆̆ı ve kolon geçişini hızlandırdığı bildirilmiştir (19).

Probiyotiklerin diyare üzerine olan etkileri, fermente süt ürünlerinin de benzer etkilere sahip olabileceğini düşündürmüştür. Konu ile ilgili yapılan bir çalışmada kefirin antibiyotik ilişkili diyareyi önlemedeki etkinliği araştırılmıştır. Randomize çift kör plasebo kontrollü olarak yürütülen çalışmaya 1-5 yaşları arasında 125 çocuk dahil edilmiştir. Çalışmada, antibiyotik alımını izleyen 14 gün süreyle kefir ya da ısı uygulanarak 
bakterileri öldürülmüş kefir kullanılmış ve diyare insidansı araştırılmıştır. Her iki grupta da benzer oranlarda (kefir \%18, plasebo \%21.9) diyare görüldüğü belirlenmiş ve kullanılan kefirin antibiyotik ilişkili diyareye karşı koruyucu olmadığı bildirilmiştir (50).

Laktoz intoleransı olan bireylerde süt yerine yoğurt gibifermentesütürünlerinin tüketilmesininintolerans şikayetlerini azalttığı bilinmektedir. Yapılan klinik bir çalışmada $20 \mathrm{~g}$ laktoz içeren süt, kefir ve yoğurt tüketimi sonrasında kefir ve yoğurdun benzer etki göstererek süte göre laktoz sindirimini kolaylaştırdığı saptanmıştır. Bu etkinin kefirdeki beta-galaktosidaz aktivite ile ilişkili olduğu öne sürülmüştür (17).

\section{SONUÇ VE ÖNERILER}

Düzenli ve yeterli miktarda süt ve süt ürünleri tüketimi yaşamın her döneminde sağlıklı bir diyetin vazgeçilmez parçasıdır. Bunun yanı sıra, son yıllardaki çalışmalar, fermente süt ürünlerinin bileşimindeki canlı mikroorganizmaların sağlığı koruyucu etkilerine dikkat çekmektedir. Fermente süt ürünleri arasında oldukça popüler olan kefir, hem besin ögesi bileşimi hem probiyotik özelliği ile fonksiyonel bir besin olarak sağlıklı bir diyetin bir parçası olabilir. Ülkemizde geleneksel olarak tüketilmesi, erişiminin kolay olması ve maliyetinin çok yüksek olmaması da bu konuda verilebilecek önerileri kolaylaştırmaktadır. Ancak günümüzde toplam süt ürünleri tüketiminden ayrı olarak kefir tüketimine ilişkin ulusal ya da uluslararası düzeyde bir öneri mevcut değildir. Kefir kullanımına ilişkin dikkat edilmesi gereken bir nokta standardizasyondur. Türk Gıda Kodeksi'nde yer alan düzenlemelere karşılık, üretilen ve kullanılan kefirlerin mikrobiyal bileşimlerinin ve miktarlarının standart olmaması kefir kullanımı ile ilişkili fizyolojik etkilerin de farklı olmasına neden olabilir. Benzer şekilde, literatürde yer alan çalışmalarda da kullanılan kefirlerin içeriği birbirinden önemli oranda farklılık göstermektedir. Bu nedenle, elde edilen sonuçların genellemesi mümkün olmamaktadır. Kefirle ilgili klinik çalışmaların da henüz çok az sayıda olduğu göz önüne alındığında kullanılan kefirin mikrobiyolojik profilininin de belirtildiği ve standardize edildiği daha çok çalışmaya gereksinim olduğu söylenebilir.

Çıkar çatışması - Conflict of interest: Yazarlar çıkar çatışması olmadığını beyan ederler. - The authors declare that they have no conflict of interest.

\section{KAYNAKLAR}

1. Ahmed Z, Wang Y, Ahmad A, Khan ST, Nisa M, Ahmad H, et al. Kefir and health: A contemporary perspective. Crit Rev Food Sci Nutr 2013;53(5):422-434.

2. Rosa DD, Dias MMS, Grzeskowiak LM, Reis SA, Conceicao LL, Peluzio M. Milk kefir: Nutritional, microbiological and health benefits. Nutr Res Rev 2017;30(1):82-96.

3. Otles S, Cagindi O. Kefir: A probiotic dairy-composition, nutritional and therapeutic aspects. Pakistan J Nutr 2003;2(2):54-59.

4. de Oliveira Leite AM, Miguel MA, Peixoto RS, Rosado AS, Silva JT, Paschoalin VM. Microbiological, technological and therapeutic properties of kefir: A natural probiotic beverage. Braz J Microbiol 2013;44(2):341-349.

5. Koçak C, Gürsel A. Kefir. Gıda 1981;6(4):11-14.

6. Garrote GL, Abraham AG, De Antoni GL. Microbial interactions in kefir: A natural probiotic drink. In: Mozzi F, Raya RR, Vignolo GM, editors. Biotechnology of Lactic Acid Bacteria. 1st ed. Blackwell Publishing; 2010. p. 327-340.

7. Kesenkaş H, Gürsoy O, Özbaş H. Kefir. In: Frias J, Martinez-Villaluenga C, Peñas E, editors. Fermented Foods In Health and Disease Prevention. 1st ed. Academic Press; 2017. p. 339-361.

8. TürKomp, Ulusal Gıda Kompozisyon Veri Tabanı, versiyon 1.0 Erişim: www.turkomp.gov.tr Erişim Tarihi: 24 Mayıs 2018.

9. T.C. Gıda, Tarım ve Hayvancılık Bakanlığı, Türk Gıda Kodeksi Fermente Süt Ürünleri Tebliği, Tebliğ No (2009/25). Resmi Gazete: 16.02.2009-27143. Erişim: http:// www.resmigazete.gov.tr/eskiler/2009/02/20090216-8. htm Erişim tarihi:24 Mayıs 2018.

10. Guzel-Seydim Z, Kök-Taş T, Greene AK. Kefir and koumiss: Microbiology and technology. In: Ylldız F, editor. Development and Manufacture of Yogurt and Other Functional Dairy Products. 1st ed. CRC Press; 2010. p. 143-163.

11. Bourrie BCT, Willing BP, Cotter PD. The microbiota and health promoting characteristics of the fermented beverage kefir. Front Microbiol 2016;7:647.

12. Irigoyen A, Arana I, Castiella M, Torre P, Ibáñez FC. Microbiological, physicochemical, and sensory characteristics of kefir during storage. Food Chem 


\section{5;90(4):613-620.}

13. Karabıyıklı Ş, Daştan S. Geleneksel ve fonksiyonel bir gıda olan kefirin mikrobiyolojik profili. Gaziosmanpaşa Üniversitesi Ziraat Fakültesi Dergisi 2016;33(1):75-83.

14. Golowczyc MA, Gugliada MJ, Hollmann A, Delfederico L, Garrote GL, Abraham AG, et al. Characterization of homofermentative lactobacilli isolated from kefir grains: Potential use as probiotic. J Dairy Res 2008;75(2):211217.

15. Diosma G, Romanin DE, Rey-Burusco MF, Londero A, Garrote GL. Yeasts from kefir grains: Isolation, identification, and probiotic characterization. World J Microbiol Biotechnol 2014;30(1):43-53.

16. Zanirati DF, Abatemarco M, de Cicco Sandes SH, Nicoli JR, Nunes ÁC, Neumann E. Selection of lactic acid bacteria from Brazilian kefir grains for potential use as starter or probiotic cultures. Anaerobe 2015;32:70-76

17. Hertzler SR, Clancy SM. Kefir improves lactose digestion and tolerance in adults with lactose maldigestion. J Am Diet Assoc 2003;103(5):582-587.

18. Lee MY, Ahn KS, Kwon OK, Kim MJ, Kim MK, Lee IY, et al. Anti-inflammatory and anti-allergic effects of kefir in a mouse asthma model. Immunobiology 2007;212(8):647654.

19. Turan I, Dedeli O, Bor S, Ilter T. Effects of a kefir supplement on symptoms, colonic transit, and bowel satisfaction score in patients with chronic constipation: A pilot study. Turk J Gastroenterol 2014;25(6):650-656.

20. Rafie N, Golpour Hamedani S, Ghiasvand R, Miraghajani M. Kefir and cancer: A systematic review of literatures. Arch Iran Med 2015;18(12):852-857.

21. Kim DH, Jeong D, Kim H, Kang IB, Chon JW, Song KY, et al. Antimicrobial activity of kefir against various food pathogens and spoilage bacteria. Korean J Food Sci Anim Resour 2016;36(6):787-790.

22. Hadisaputro S, Djokomoeljanto RR, Judiono, Soesatyo $\mathrm{MH}$. The effects of oral plain kefir supplementation on proinflammatory cytokine properties of the hyperglycemia wistar rats induced by streptozotocin. Acta Med Indones 2012;44(2):100-104.

23. Choi JW, Kang HW, Lim WC, Kim MK, Lee IY, Cho HY. Kefir prevented excess fat accumulation in diet-induced obese mice. Biosci Biotechnol Biochem 2017;81(5):958965.

24. Pereira MCA, Barcelos MFP, Sousa MSB, Pereira JAR. Effects of the kefir and banana pulp and skin flours on hypercholesterolemic rats. Acta Cir Bras 2013;28(7):481486.

25. Arqués JL, Rodríguez E, Langa S, Landete JM, Medina M. Antimicrobial activity of lactic acid bacteria in dairy products and gut: Effect on pathogens. Biomed Res Int $2015 ; 2015$.
26. Ulusoy BH, Çolak H, Hampikyan H, Erkan ME. An in vitro study on the antibacterial effect of kefir against some food-borne pathogens. Türk Mikrobiyoloji Cemiyeti Dergisi 2007;37(2):103-107.

27. Silva KR, Rodrigues SA, Filho LX, Lima AS. Antimicrobial activity of broth fermented with kefir grains. Appl Biochem Biotechnol 2009;152(2):316-325.

28. Rodrigues KL, Caputo LR, Carvalho JC, Evangelista J, Schneedorf JM. Antimicrobial and healing activity of kefir and kefiran extract. Int J Antimicrob Agents 2005;25(5):404-408.

29. Bekar O, Yilmaz Y, Gulten M. Kefir improves the efficacy and tolerability of triple therapy in eradicating helicobacter pylori. J Med Food 2011;14(4):344-347.

30. Ahmed AU. An overview of inflammation: Mechanism and consequences. Front Biol 2011;6(4):274-281.

31. Lescheid DW. Probiotics as regulators of inflammation: A review. Functional foods in health and disease 2014;4(7):299-311.

32. Kim DH, Kim H, Jeong D, Kang IB, Chon JW, Kim HS, et al. Kefir alleviates obesity and hepatic steatosis in high-fat diet-fed mice by modulation of gut microbiota and mycobiota: Targeted and untargeted community analysis with correlation of biomarkers. J Nutr Biochem 2017;44:35-43.

33. Adiloğlu AK, Gönülateş N, İşler $M$, Şenol A. Kefir tüketiminin insan bağışıklık sistemi üzerine etkileri: Bir sitokin çalışması. Mikrobiyol Bul 2013;47(2):273-281.

34. de Moreno de LeBlanc A, Matar C, Farnworth E, Perdigon G. Study of cytokines involved in the prevention of a murine experimental breast cancer by kefir. Cytokine 2006;34(1-2):1-8.

35. Liu JR, Wang SY, Lin YY, Lin CW. Antitumor activity of milk kefir and soy milk kefir in tumor-bearing mice. Nutr Cancer 2002;44(2):183-187.

36. Schwingshackl L, Hoffmann G, Schwedhelm C, KalleUhlmann T, Missbach B, Knüppel S, et al. Consumption of dairy products in relation to changes in anthropometric variables in adult populations: A systematic review and meta-analysis of cohort studies. PLoS One 2016;11(6):e0157461.

37. Fathi Y, Faghih S, Zibaeenezhad MJ, Tabatabaei SH. Kefir drink leads to a similar weight loss, compared with milk, in a dairy-rich non-energy-restricted diet in overweight or obese premenopausal women: A randomized controlled trial. Eur J Nutr 2016;55(1):295-304.

38. Sun J, Buys N. Effects of probiotics consumption on lowering lipids and CVD risk factors: A systematic review and meta-analysis of randomized controlled trials. Ann Med 2015;47(6):430-440.

39. Shimizu M, Hashiguchi M, Shiga T, Tamura HO, Mochizuki M. Meta-analysis: Effects of probiotic 
supplementation on lipid profiles in normal to mildly hypercholesterolemic individuals. PLoS One 2015;10(10):0139795.

40. Cho YA, Kim J. Effect of probiotics on blood lipid concentrations: A meta-analysis of randomized controlled trials. Medicine(Baltimore)2015;94(43):e1714.

41. Maeda H, Zhu X, Omura K, Suzuki S, Kitamura S. Effects of an exopolysaccharide (kefiran) on lipids, blood pressure, blood glucose, and constipation. Biofactors 2004;22(1-4):197-200.

42. St-Onge MP, Farnworth ER, Savard T, Chabot D, Mafu A, Jones PJ. Kefir consumption does not alter plasma lipid levels or cholesterol fractional synthesis rates relative to milk in hyperlipidemic men: A randomized controlled trial [ISRCTN10820810]. BMC Complement Altern Med 2002;2:1.

43. Ostadrahimi A, Taghizadeh A, Mobasseri M, Farrin N, Payahoo L, Beyramalipoor Gheshlaghi Z, et al. Effect of probiotic fermented milk (kefir) on glycemic control and lipid profile in type 2 diabetic patients: A randomized double-blind placebo-controlled clinical trial. Iran J Public Health 2015;44(2):228-237.

44. Robles-Vera I, Toral M, Romero M, Jimenez R, Sanchez M, Perez-Vizcaino F, et al. Antihypertensive effects of probiotics. Curr Hypertens Rep 2017;19(4):26.

45. Ong L, Shah NP. Release and identification of angiotensin-converting enzyme-inhibitory peptides as influenced by ripening temperatures and probiotic adjuncts in cheddar cheeses. LWT Food Sci Technol 2008;41(9):1555-1566.

46. Friques AGF, Arpini CM, Kalil IC, Gava AL, Leal MA, Porto ML, et al. Chronic administration of the probiotic kefir improves the endothelial function in spontaneously hypertensive rats. J Transl Med 2015;13:390.

47. Kanbak G, Uzuner K, Kusat Ol K, Oglakci A, Kartkaya $\mathrm{K}$, Senturk H. Effect of kefir and low-dose aspirin on arterial blood pressure measurements and renal apoptosis in unhypertensive rats with 4 weeks salt diet. Clin Exp Hypertens 2014;36(1):1-8.

48. Rosa DD, Grzeskowiak LM, Ferreira CL, Fonseca AC, Reis SA, Dias MM, et al. Kefir reduces insulin resistance and inflammatory cytokine expression in an animal model of metabolic syndrome. Food Funct 2016;7(8):3390-3401.

49. T.C. Gıda, Tarım ve Hayvancılık Bakanlığı, Türk Gıda Kodeksi Beslenme ve Sağllk Beyanları Yönetmeliği. Resmi Gazete: 26.01.2007-29960. Erişim: http://www. resmigazete.gov.tr/eskiler/2017/01/20170126M1-5.htm Erişim tarihi:24 Mayıs 2018.

50. Merenstein DJ, Foster J, D'Amico F. A randomized clinical trial measuring the influence of kefir on antibiotic-associated diarrhea: The measuring the influence of kefir (milk) study. Arch Pediatr Adolesc Med 2009;163(8):750-754. 